\title{
The conceptualisation of "soft skills" among medical students before and
} after curriculum reform

\author{
CWVan Staden ${ }^{1}$, PIM Joubert ${ }^{1}$, GE Pickworth ${ }^{2}$, JL Roos ${ }^{1}$, A-M Bergh ${ }^{3}$, C Krüger ${ }^{1}$, WJ Schurink ${ }^{4}$, RR Du Preez ${ }^{1}$, SV Grey ${ }^{5}$, BG Lindeque $^{6}$ \\ ${ }^{1}$ Department of Psychiatry, Faculty of Health Sciences, University of Pretoria, South Africa \\ ${ }^{2}$ Education Consultant, Faculty of Health Sciences, University of Pretoria, South Africa \\ ${ }^{3}$ Education Office, Faculty of Health Sciences, University of Pretoria, South Africa \\ ${ }^{4}$ Social Science Research Consultancy (SSRC), Pretoria, South Africa \\ ${ }^{5}$ Faculty of Health Sciences, University of Pretoria \\ ${ }^{6}$ Department of Obstetrics and Gynaecology, Faculty of Health Sciences, University of Pretoria, South Africa
}

\begin{abstract}
Objective: This paper reports on the conceptualisation of "soft skills" as part of a study carried out among two groups of undergraduate medical students before and after curriculum reform at the School of Medicine of the University of Pretoria. Congruent with a call from the World Psychiatric Association, the curriculum reform that was undertaken aimed, inter alia, to place more emphasis on soft skills, including professional interpersonal and social skills, communication skills, and professional and ethical attitudes. Methods: Qualitative methods were used to arrive at a descriptive comparison of the conceptualisation of soft skills by final-year medical students of the traditional curriculum with those of final-year students who had followed the reformed curriculum. A purposive-theoretical sampling method was followed; 42 students from the traditional curriculum and 49 from the reformed curriculum were sampled. Data were collected from seven focus groups, 16 individual interviews, and 23 essays (autobiographical sketches). Results: Both groups of students revealed conceptualisations of soft skills that were similar in kind. The themes they pinpointed were the doctor-patient relationship; relationships with other professionals; being a good listener; explaining things to patients; using good communication skills; establishing rapport with patients from different cultural backgrounds; having a professionally correct attitude; being really interested in patients' well being; having empathy; coping with patients, managing difficult situations, and being ethical and professional. However, the traditional curriculum students offered fewer examples and described fewer experiences that exemplified their soft skills. Students following the reformed curriculum gave rich accounts of their conceptualisation in terms of their own experiences and practical examples of how soft skills had been or could be used, particularly in difficult interpersonal situations. Moreover, they came up with helpful ways of dealing with difficult situations, which surpassed the suggestions offered by the students following the traditional curriculum. Conclusion: The educational and training efforts of the reformed curriculum are associated with an adeptness on the part of the students at applying soft skills to the demands of difficult clinical situations.
\end{abstract}

Keywords: Soft skills; Interpersonal skills; Doctor-patient relationship; Professional socialisation

Received: 02.12.04

Accepted: 13.06 .05

\section{Correspondence:}

Dr PM Joubert

Department of Psychiatry, Faculty of Health Sciences,

University of Pretoria,

PO Box 667, Pretoria, 0001, South Africa

email: pm.j@icon.co.za

\section{Introduction}

In 1997 a reformed curriculum was implemented for medical students at the University of Pretoria. A critical aspect of the curriculum reform was a shift towards attention to attitudes, communication and other professional skills. Following international trends, this shift was made at the deliberate expense of the traditional factual overload, working instead 
towards students' becoming lifelong learners. ${ }^{2}$ Various programmes were designed and implemented locally for the development of these skills and attitudes, which we collectively called "soft skills".

One critical test for this curriculum reform lies in the assessment of the students' resulting qualitative insights into and adeptness at applying soft skills. The objective of this study was to examine qualitatively the conceptualisation of, and adeptness at, soft skills as portrayed in students' reflections on their training and practical experiences, as well as in practical examples in which soft skills are relevant.

This paper aims to help psychiatrists improve their understanding of students' appreciation of soft skills, which in turn may help them to be better role models to students. It reports on the conceptualisation of soft skills in a study among medical students before and after curriculum reform. It describes students' appreciation of what soft skills are about, and it precedes a paper that reports on the principal way in which students acquire their soft skills - namely through psychiatrists and other clinicians being role models to them. ${ }^{2}$

\section{Methods}

A qualitative study design was followed, the details of which as applied to this study are described elsewhere..$^{3,4}$ Data from two groups of students were gathered at the end of 2001 and 2002 respectively. The first group consisted of final-year students from the traditional six-year curriculum, and the second group consisted of the first final-year students from the reformed six-year curriculum. Following a qualitative, process-evaluation design with purposive-theoretical sampling, 42 students from the traditional curriculum and 49 from the reformed curriculum were selected for participation in seven focus groups, 16 individual interviews and the compilation of 23 autobiographical sketches. ${ }^{1}$

A semi-structured guide was followed for conducting the focus groups and the individual interviews. For the autobiographical sketches, the information leaflet and informed consent forms included an outline of topics that the research participants could consider when writing sketches. The semi-structured guide and the outline of topics for the autobiographical sketches can be obtained from the researchers.

Data were captured from audio tape recordings, transcripts of the audio tapes, researcher field notes, and the written accounts of the students. The analysis of the data was guided by grounded theory, and symbolic interactionism was chosen as the methodological framework for this study.

\section{Results}

On the surface, both groups of students revealed conceptualisations that were similar in kind - showing similar perceptions of what soft skills are about. Upon closer scrutiny, however, differences between the two groups were apparent in the use of the concepts related to soft skills. These differences relate to students' awareness and the extent to which they were able to apply soft skills to meet the demands of difficult clinical situations.

\section{What are soft skills about?}

Both groups emphasised that soft skills are displayed in, and have to do with, interpersonal skills.
Op die einde van die dag is dit eintlik interpersoonlike vaardighede ${ }^{a}$. Jy sien die pasiënt, die ander mense in die saal, die susters. Dis nogal 'n groot deel van jou kommunikasietyd. [At the end of the day it's really about interpersonal skills. ${ }^{a}$ You see the patient, the other people in the ward, the sisters. That's quite a lot of your communication time.]

The way you manage your patients as a person and not a disease/syndrome is what interpersonal skills are all about. Explaining things before you do it, respecting their wishes or opinions, treating them with dignity, being subjective, allowing the patient to help you in your decision-making - these are soft skills...

Although they mostly considered the relationship between doctor and patient, they also mentioned interpersonal relationships between doctors and between doctors and other health professionals - "Ja, en hoe jy met kollegas omgaan en met jou seniors en jou juniors en daardie verhoudings." ['Yes, and how you relate to your colleagues and your seniors and juniors and those relationship..']

Good communication skills are part of soft skills: "Good communication skills could help a doctor develop a good doctor-patient relationship." If one is to communicate well, one should be a good listener. The ability to be a good listener featured in just about all the students' descriptions of soft skills.
... naamlik 'n goeie luisteraar is, die vermoë het om 'n moeilike situasie te identifiseer en te hanteer sonder konflik, empatie te betoon met die oordra of aanhoor van slegte nuus, en om opreg belang te stel in hul pasiënt se wel en weë.

\begin{abstract}
[... namely good listeners have the ability to identify a difficult situation and handle it without conflict, to show empathy when they have to give or hear bad news, and to take a genuine interest in their patient's well-being.]
\end{abstract}

They link good listening with good explanations. "You try and explain something to them. You don't go into detail but at least make sure...".; and "Ek dink dit is daardie ... verduidelik wat presies aan die gang is.". [ "I think it's that word explain that conveys what is going on here."']. Doing so, will help with another soft skill, namely the establishment of rapport with patients from different cultural backgrounds. "Sagte niekliniese vaardighede is, soos ek reeds beskryf het, hoe om verskillende pasiënte uit verskillende agtergronde, kulture, ens. te benader om rapport te bemeester." ["Soft, non-clinical skills are, as I have already explained, how to approach different patients from different backgrounds, cultures etc in order to master rapport.']

"Bedside manners" was a term used to denote soft skills, defined as "die manier waarop die dokter met die pasiënt interaksie het." ["the way the doctor interacts with the patient.']

In their conceptualisation of soft skills students 
emphasised a genuine interest in the patient's well-being and "om opreg belang te stel in hul pasiënt se wel en weë" [" to take a genuine interest in their patient's well-being.'”. This also covered the question of treating patients decently: "I think we each have our own ideal of what we want a doctor to do. I tend with most of my patients to treat them the way I would like to be treated when I can and I have the time."

Empathy featured strongly in their conceptualisation.

Een van die belangrikste vaardighede wat aangeleer moet word, is empatie. Vanuit 'n pasiënt se oogpunt dink ek is empatie en begrip baie keer belangriker as kennis en vaardigheid. [One of the most important skills that must be learned is empathy. From a patient's point of view I often think that empathy and understanding are often more important than knowledge and skills.]

A respectful attitude was highlighted as another soft skill. "It is important to respect your patient from the beginning." Respect "makes a huge difference" and "there is no excuse for being rude." Respect should not be limited to patients, but extended to colleagues, students, nurses, and anyone the doctor is working with - "Respect for the patient, respect for the colleagues. Respect. Colleagues. It's either a student, it's either a nurse, it's either anyone who's working with you."

Ethics and professionalism were part of students' conceptualisation: "nie-kliniese vaardighede loop hand-aanhand met professionele en etiese houdings. ["non-clinical skills go hand in hand with professionalism and ethical attitudes.]

Two other recurrent themes were honesty and trust. Persoonlik stel ek eerlikheid baie hoër as in beheer bly, of outoritêr wees" and "You must give them your trust first and be there to listen to them and ... make them feel like ... you're there for them." ["Personally I put a much higher value on honesty than on staying in control, or being authoritarian "]

Showing ... you really care for them. Let them speak out, like you listen to what their problem [is]. And then at a time some of them don't want to open up at first, but with time, when they realise that you really want to know what's wrong with them they start opening up. And then they start to develop, like realise that they can trust you.

\section{Awareness of and adeptness at soft skills}

Reformed curriculum students praised the teaching efforts, even though any teaching of soft skills was considered to be a mere aid, whereas traditional curriculum students repeatedly bemoaned their lack of soft skills, and occasionally expressed the wish that such skills could be taught.

\section{Traditional curriculum students:}

- Ek dink nie ons dink ooit daaroor nie. [I don't think we ever consider that.]

- Ek dink ons is baie swak toegerus [met professionele vaardighede]. [I think we are very badly equipped [with pro[essional skills].
- Ek dink die kursus op sigself leer jou glad nie die skills nie [I think the course in itself doesn't teach you those skills.]

- But no-one actually taught us [soft skills].

\section{Reformed curriculum students:}

- Die leerplan doen sy bes om ons die 'soft skills' te leer ..." [The curriculum really tries to teach us the 'soft skills'...']

- There was a wonderful attempt made theoretically to also teach me about the emotional aspects of medicine and this too was appreciated."

- Ek voel dat nie-verbale gedrag redelik goed aangespreek is op verskeie plekke in ons kursus, maar weer eens dat sommige mense hierdie vaardighede sal gebruik en probeer verbeter en ander nie." [I feel that non-verbal behaviour was fairly well-addressed at various points in our course, but then again some people will use these skills and try to improve them and others won't.']

However, awareness of and training in soft skills do not necessarily result in adeptness, even if students are better equipped by the reformed curriculum. A more convincing difference between the student groups transpired in their practical conceptualisations of soft skills in difficult interpersonal situations, even though both groups of students revealed conceptualisations of soft skills that were similar in kind (see above). Students of the reformed curriculum came up with helpful ways, often based on their own experiences, of dealing with difficult situations, which surpassed those offered by the traditional curriculum students. They also gave rich accounts of their own experiences and provided practical examples of how soft skills had been or could be used hypothetically, whereas the traditional curriculum students offered fewer examples and accounts of experiences that exemplified their soft skills.

Thus, the data elicited from the reformed curriculum students exceeded the saturation of themes offered by the traditional curriculum students in considering difficult interpersonal situations - whether they had actually experienced or had to imagine them. This will be shown in the examples below, about their dealing with an aggressive patient, a patient who is reluctant to talk, a patient who is in love with the doctor or student, and the doctor's or student's falling in love with a patient.

In relation to aggressive patients, the traditional curriculum students seemed more restricted in their ways of dealing with them, felt inadequately equipped to do so, and related incidents in which they could not be empathetic and became angry themselves.

- $\quad$ Ek word terug kwaad. Want dis soos ek het niks aan jou gedoen nie, moenie vir my skree nie. [I get angry right back. Because if I've done nothing to the patient what gives her the right to scream at me?]

- I would immediately be stern and say, "If you don't let me help you, this is what is going to happen, these are the complications. You have a choice - either you, it's me or no-one", and then you leave. And I don't know if that is the right attitude. ... But at that point it is so frustrating that you become nasty.

- "You just tell him...it's either me or nothing." Upon which a fellow student responded: "I get very aggressive. I know it's bad. And I really have to work on it." 
On the other hand, students from the reformed curriculum seemed more resourceful in dealing with aggressive patients.

- I mean "difficult patients" is a wide thing. It depends on, there are those that would need sedation, there are those that would need the securities personnel. You must know what to look for, I mean, if there are those patients that are so difficult that you need to call the registrar to come in, because you are not fully equipped say to prescribe medication. I mean as a student you cannot prescribe certain medication. You have to know who to contact if you need help, if the situation is out of hand ... difficult situation. Sometimes the nurses they can handle the situation ... just do this. But with time, as we gain experience, you have difficult, I mean, the difficulty that you encounter you can be able to solve them like [if] a patient doesn't want to take medication ... Sometimes they just need a doctor to talk to them and they just understand that it is necessary to take the medication and the difficulty goes down.

- Dan moet jy kalm en rustig bly en probeer om rustig met die pasiënt ... as die pasiënt aggressief raak en ongelukkig is, net mooi verduidelik, kom sit nou, wat pla jou, eers vra[vir] die pasiënt wat pla en dan sê wat jy kan doen. Partykeer kan jy nie iets verander wat ... kyk of jy kan verander, wat jy kan doen om te help. As jy moet kwaad raak of ongelukkig raak, dan kan jy nie iets doen nie. [That's when you have to stay calm and relaxed. If the patient seems aggressive and unhappy, then you calmly ask the patient to come and sit down and tell you what's the matter. Then you explain to the patient what you could do to help. Maybe there'll be things that you can't change, but see if there's anything you can do. If you're angry and upset, you can't do anything for your patient.]

In dealing with patients who are reluctant to talk, both groups emphasised the need to spend time with them.

Mens kan later terugkom, ... dan kan jy vir die pasiënt sê, "Meneer/mevrou ek het nie nou tyd nie, ek wil eerder rustig met jou kom praat. Ek kom nou-nou terug dan gesels ons lekker wanneer ek nie vinnig by 'n plek moet wees nie. [You could go back later, ... then you say to the patient, "Sir/ma'am I really don't have time now, and I'd like to give enough time to discussing this. I'll be back in a little while and then we can have a nice chat when I'm not rushing to get somewhere.]

Reformed curriculum students went further and elaborated on the process they would follow to resolve the difficulty when patients do not want to talk.

- Sometimes you find the patients don't want to talk because they have underlying fears. So you can start there. Because sometimes they almost have preconceived ideas of what might be wrong. So they decide, no I'm not going to tell that, no I'm not going to ... Maybe if you start there and you ask directly, then the patient [will say], you'll know, I thought this and this and this. Then if you can allay those fears, then the patient will start opening up to you.
- Mens moet seker dan bepaal hoekom die pasiënt stil is in die eerste plek. Dit, is hy bang, is daar'n taalkommunikasieprobleem? So ek dink mens moet by die probleem uitkom, hoekom hy stil is, want dis dan ook half'n teken. Dis miskien dan 'n"'soft silence", en dan wil mens nou, dan via daardie probleem sy ware probleem aanspreek. [I suppose one starts by finding out why the patient is so quiet in the first place. Is he plain scared, is there a language communication problem? So I think one has to get to the root of the problem of why the patient is so quiet because that's almost a sign. Maybe it's a 'soft silence", and then via that problem you'll be able to deal with his real problem.]

- Maybe sometimes it may be that the patient is not a talkative kind of a person. So you need to understand that.

- You know the doctor is not the only person around the patient. There are also sisters, there are all of us, there are the social workers. If you suspect, I mean you tend to talk of the sisters, "How's this patient?" Maybe try to involve the sisters to talk about this patient. Maybe they might open up to the sisters, maybe they'd open up to the student. Maybe the patient need[s] a psychology counsellor ... that could reach the patient ... so in collaborating with such people that have established a relationship.

Traditional curriculum students seemed less prepared for the possibility of romantic advances from patients, and some were oblivious to their own potential interest in a patient. Some suggested simple solutions such as, "jy ignoreer dit". Others saw the situation as clear-cut - "you can never let that happen". After some debate in one of the focus groups, they expressed their doubts about being ready to deal with such a situation.

- If you start by walking into the door it's already a professional situation. I don't even let the thought cross my mind. No matter how pretty she is. Sometimes you think, "Ah she's good looking"' But I just don't think about it.

- Dan sal ek maar vir hom sê cheers en eerder die pasiënt verloor.[Then I'd tell him cheers and rather lose the patient.]

The reformed curriculum students seemed more prepared to deal with an infatuation in that they reflected on the process through which an infatuation could develop.

- Like with my patient I started asking, oh myself maybe I was too nice ... Maybe you're trying to be nice to patients and listen to their problems and maybe I overdid it.

- Ek dink dis 'n goeie uitgangspunt en idealisties om te sê ja, dis die pasiënt-dokter-verhouding, en dis hoe dit is, maar in die realiteit werk [dit] nie so nie. Dis maar nou net een van daardie dinge. Ek dink mens moet eerder op realiteit werk as wat jy op onrealistiese doelstellings werk ... Ek dink maak die beste van 'n saak, of dit nou'n goeie of slegte saak is. [I think it's a good approach and it's idealistic to say yes, that's the patient-doctor relationship and that's the way it is, but in reality it doesn't work like that. That's just one of those things. And I think one needs to work with reality rather than with unrealistic goals ... I think, make the best of things, for better or worse.] 
Furthermore, students of the reformed curriculum expressed - rather explicitly in comparison with the traditional curriculum students - the expectation of life-long learning in relation to their soft skills.

- Dit is egter 'n aanhoudende proses en gaan nooit voltooi wees. [ It's an ongoing process and it will never be finished.]

- Ek dink die "soft skills" wat ek geleer het, het nog baie skaafwerk nodig, maar ook dat die basis daar gelê is vir verdere verbetering. [I think the 'soft skills' that I learned need a lot of refining, but we have been given a basis to build on.]

- The doctor also has a responsibility to deal with his own emotions and know his limitations and recognise and work on weaknesses.

- So as long as you have an inclination to self-improvement, in all aspects of your life, you are well on your way to be a "good" everything included [a good] doctor.

\section{Discussion}

Both student groups underlined the importance of soft skills in medical practice, and both groups had similar ideas about soft skills. However, reformed curriculum students gave an account of their conceptualisation in terms of their own experiences and supplied practical examples of how soft skills had been or could be used, whereas the traditional curriculum students offered fewer examples and experiences that exemplified their soft skills. This was particularly evident in their practical approach to soft skills in difficult interpersonal situations. They came up with helpful ways, often based on their own experiences, of dealing with difficult situations, which surpassed those offered by the traditional curriculum students.

Reformed curriculum students seemed more prepared, and felt that teaching and training efforts left them wellequipped with soft skills. This may be the result of some of the "golden threads" that had been woven "horizontally" across all six years into the learner-centred, problem-oriented curriculum for attaining competencies that included interpersonal skills and professional, ethical attitudes. In the process soft skills were emphasised much more than before.

Regarding skills and attitudes, the Health Professions Council of South Africa (HPCSA) objectives require inter alia that medical curricula accentuate communication skills; respect for patients and colleagues without prejudice with regard to background, race, culture, gender, way of life, et cetera; recognition of human and patients' rights; approaches to learning which are based on an inherent wish to acquire and explore knowledge that will be retained throughout the individual's professional life instead of a passive acquisition of knowledge; a positive approach towards self-directed lifelong learning; an awareness of moral and ethical responsibilities; an awareness of personal limitations and a willingness to seek help; and a positive attitude towards continuing professional development. ${ }^{7}$

\section{Conclusion}

This study suggests that the envisaged curriculum reform has impacted on students' conceptualisation of soft skills. It is encouraging, furthermore, that the students' conceptualisations of skills are well aligned with the objectives of the HPCSA.

Students' conceptualisation of soft skills is also well aligned with the international standard in medical education, which requires each school to have a clear plan to ensure that the necessary attitudes have been acquired by the time the students graduate. ${ }^{8}$ Similar to the conceptualisation of our students, the international standards include: lifelong learning; the ability to work constructively with other health professionals; desirable attitudes towards patients and their families in which students respect patients and understand their feelings and recognise the necessity for good doctorpatient relationships. The World Psychiatric Association emphasised that training in these attitudes and skills should be part of the core curriculum in psychiatry. ${ }^{8}$

\section{Notes}

- Emphasis in direct quotations added by the authors.

\section{Acknowledgements}

This publication would not have been possible without the tremendous willingness and openness of the students who participated in this study. The financial, professional and logistic support of the Departments of Obstetrics and Gynaecology and Psychiatry, the Education Office and the Deputy Dean's Office of the Faculty of Health Sciences is acknowledged with gratitude. The views expressed in this paper are those of the authors and not necessarily those of the sponsors. Ethical approval for conducting this study was given by the Research Ethics Committee of the Faculty of Health Sciences, University of Pretoria (No S183/2001).

\section{Declaration of interest}

Willem Schurink was paid for his participation and consultation work from funds from the departments mentioned above.

\section{References}

1. General Medical Council (Educational Committee). Tomorrow's doctor: Recommendations on undergraduate medical education. London: GMC; 1993.

2. Joubert PM, Krüger C, Bergh A-M, Pickworth GE, Van Staden CW, Roos JL, et al. Medical students on the value of role models for developing "soft skills": "That's the way you do it". S Afr Psychiatry Rev, 2006;9(1):28-32.

3. Schurink WJ, Krüger C, Bergh A-M, Roos JL, Pickworth GE, Van Staden CW, et al. "Soft skills" among medical students at the University of Pretoria before and after curriculum reform: a methodological appraisal. Unpublished manuscript; 2003.

4. Denzin NK, Lincoln YS, editors. Handbook of qualitative research. 2nd edition: Thousand Oaks, CA: Sage; 2000.

5. Strauss A, Corbin J. Basics of grounded theory procedures and techniques. Newbury Park, CA: Sage; 1990.

6. Blumer H. Symbolic interactionism, perspective and method. Englewood Cliffs, NJ: Prentice-Hall; 1969

7. HPCSA (Health Professions Council of South Africa). Education and training of doctors in South Africa: Undergraduate medical education and training. Pretoria: Education Committee of the Medical and Dental Professional Board, HPCSA; 1999.

8. Sartorius N, Costa de Silva JA. Core curriculum in psychiatry for medical students. World Psychiatric Association and the World Federation for Medical Education. Med Educ 1999; 33:204-21. 